\title{
THE MODELS OF CHARACTER AND AKHLAQ EDUCATION FOR SPECIAL NEEDS CHILDREN IN AN INCLUSION SCHOOL
}

\author{
Manpan Drajat', Mohd Roslan Mohd Nor ${ }^{2}$ \\ 'Sekolah Tinggi Agama Islam (STAI) DR. KH. EZ. Muttaqien Purwakarta, Indonesia \\ Jl. Baru Maracang No. 35, Kecamatan Maracang, Kabupaten Purwakarta \\ E-Mail: manvandrajat44@gmail.com \\ ${ }^{2}$ University of Malaya (UM), Malaysia \\ Jl. Universiti, 50603 Kuala Lumpur, Wilayah Persekutuan Kuala Lumpur, Malaysia \\ E-Mail: m_roslan@um.edu.my
}

\begin{abstract}
The law stresses that education is the right of all citizens, including children with special needs. The need for education is the same as school-age children in general, but the training provided is adjusted to the specifics of the children. It is certainly guaranteed that all children need character education and akhlaqul karimah. This research aims to explore how character education and akhlaq in children with special needs in Al-Ghazali Jatinangor Inclusion Elementary School. The method used is phenomenological quality research. The data is collected in by observations, interviews, documentations, and Focus Group Discussion (FGD). Then, it was analyzed using interactive analysis techniques. The results indicate that the education program at Al-Ghazali Inclusion Elementary School is different from most other elementary schools. It has long hours of activities and most of the time conducted at school activities are filled with daily routines that build consistent characters and akhlaqul karimah for both children.
\end{abstract}

Keywords: character education; akhlaq; children with special needs; inclusive schools.

\begin{abstract}
Abstrak: Undang-undang menegaskan bahwa pendidikan adalah hak semua warga termasuk anak berkebutuhan khusus. Kebutuhan akan pendidikan anak berkebutuhan khusus sama dengan anak usia sekolah pada umumnya, akan tetapi pendidikan yang diberikan tentu disesuaikan dengan kekhususan anak tersebut. Namun dapat dipastikan bahwa semua anak termasuk anak berkebutuhan khusus membutuhkan pendidikan karakter dan akhlak mulia. Penelitian ini bertujuan untuk mengeksplorasi bagaimana pendidikan karakter dan akhlak pada anak berkebutuhan khusus di Sekolah Dasar (SD) Inklusi Al-Ghazali Jatinangor Sumedang. Metode yang digunakan penelitian ini adalah penelitian kualitatf fenomenologi. Data penelitian ini dikumpulkan dengan observasi, wawancaran, dokumentasi dan Focus Group Discussion (FGD). Data dianalisis dengan teknik interactive analysis. Hasil penelitian ini menunjukkan bahwa program pendidikan di SD Inklusi Al-Ghazali Jatinangor ini berbeda dengan kebanyakan SD lainnya yaitu jam kegiatan yang panjang yang sebagian besar waktu kegiatan di sekolah diisi dengan kegiatan sehari-hari yang membangun karakter dan akhlak mulia yang dilakukan secara konsisten, baik untuk anak normal mupun anak berkebutuhan.
\end{abstract}

Kata kunci: pendidikan karakter; akhlak; anak berkebutuhan khusus; sekolah inklusi.

\section{Introduction}

More than 93 million children in the world live in disability conditions, ${ }^{1}$ as well as in Indonesia, around 1.6 million children are living in disabilities or with special needs ${ }^{2}$, the number

1 "Inclusive Education" |UNICEF,", https://www.unicef. org/education/inclusive-education. accessed March 2, 2020.

2 "70 Persen Anak Berkebutuhan Khusus Tak Dapat in the field can be more than the above figure because it suspected there are still many children with special needs who have not recorded. Like children in this world, they have the same dreams and hopes about their future. Unfortunately, they

Pendidikan Layak", https://lifestyle.bisnis.com/read/20190326/ 236/904431/70-persen-anak-berkebutuhan-khusus-tak-dapatpendidikan-layak, accessed March 2, 2020. 
often escape the attention of policymakers. They usually get limitations on access to education, universal access, and other access.

Regarding access to education, for example, according to Dapodik data in 2018, the distribution of students with disabilities in Indonesia has 993,000 students 3 . In other words, there are still approximately 600 thousands of them who have not received educational services. Similarly, statistical data in 2019, the figures above are not much different from previous data. It shows that the participation of children with special needs education is still low each year ${ }^{4}$. As can be seen from the following statistical data table:

\begin{tabular}{|c|c|c|c|c|}
\hline \multirow{2}{*}{\multicolumn{2}{|c|}{ Demographic Characteristics }} & \multicolumn{3}{|c|}{ School Participation } \\
\hline & & \multirow{2}{*}{ No/never attended school } & \multirow{2}{*}{$\begin{array}{c}\text { Stillinschool } \\
\text { (3) }\end{array}$} & \multirow{2}{*}{$\begin{array}{l}\text { Never attended } \\
\text { school anvmore } \\
\text { (4) }\end{array}$} \\
\hline & (1) & & & \\
\hline Total & & 6,40 & 2495 & 68,65 \\
\hline \multicolumn{5}{|l|}{ Gender } \\
\hline Male & & 5,33 & 25,29 & 69,38 \\
\hline Female & & 7,47 & 24,61 & 67,92 \\
\hline \multicolumn{5}{|l|}{ Regional Type } \\
\hline Urban & & 4,96 & 25,56 & 69,48 \\
\hline Rural & & 8.22 & 24,18 & 67,60 \\
\hline \multicolumn{5}{|l|}{ Disability Status } \\
\hline Non-disability & i & 5,97 & 25.49 & 6854 \\
\hline Disability & & 21,39 & 5,90 & 72.71 \\
\hline \multicolumn{5}{|l|}{ Age Group } \\
\hline & & 9821 & 1,74 & 0,05 \\
\hline 6 & & 59,86 & 39,78 & 0,36 \\
\hline $7-12$ & & 0,49 & 99.24 & 0.27 \\
\hline $13-15$ & & 0,38 & 95,51 & 4,11 \\
\hline $16-18$ & & 0,58 & 72,36 & 27,06 \\
\hline $19-24$ & & 0,76 & 25.21 & 74,03 \\
\hline $25+$ & & 4,90 & 0,79 & 94,31 \\
\hline \multicolumn{5}{|c|}{ Household Economic Status } \\
\hline Quintile 1 & thentos & 10.08 & 26,16 & 63,76 \\
\hline Quintle 2 & & 7,15 & 25,95 & 6690 \\
\hline Quinite 3 & & 6,14 & 25.21 & 68.65 \\
\hline Qinitle 4 & & 5,26 & 23,66 & 71,08 \\
\hline Quintile 5 & & 3,53 & 23,86 & 72,61 \\
\hline
\end{tabular}

Source: BPS, Susenas March 2019

In fact, in the service of education, all countries understand that education is a fundamental part of human equality ${ }^{5}$. Likewise,

3 "Jumlah Data Masuk Siswa Disabilitas di Sekolah Inklusif Masih Sedikit", https://edukasi.kompas.com/ read/2019/11/28/14021431/jumlah-data-masuk-siswa-disabilitasdi-sekolah-inklusif-masih-sedikit?page=all, accessed March 9, 2020,

4 "Potret Pendidikan Statistik Pendidikan Indonesia 2019", https://www.bps.go.id/publication/2019/11/29/1deb58 8ef5fdbfba3343bb51/potret-pendidikan-statistik-pendidikanindonesia-2019.html, accessed February 29, 2020,

5 Ika Devi Pramudiana,"Implementasi Kebijakan Pendidikan Inklusif Untuk Abk di Surabaya" Jurnal Dimensi Pendidikan dan Pembelajaran, vol.5, no.1 (2017), pp.1-9, doi:http://dx.doi.org/10.24269/dpp.v5i1.317, accessed March 9, 2020. in the country of Indonesia, in Law No. 20 of 2003 concerning the National Education System Chapter IV, Article 5 paragraph 1 states that every citizen has an equal opportunity to obtain a quality education. Next, in section 2, it is explained more specifically that children with special needs have the right to receive special education services. Thus, it is apparent in the law that every child in Indonesia without exception is entitled to get excellent education services, including children with special needs. ${ }^{6}$

Moreover, Indonesia as a country whose majority is Muslim has become an obligation as a Muslim and supportive community to glorify human beings including praising them by not discriminating against their conditions and not discriminating against their rights including the right to obtain a quality education.

Like normal children in general, children with special needs require quality education. Of course, the needs will be highly adapted to the special conditions of the child. But it is most certain that they need character education and akhlaq education.?

Character education and akhlaq are essential for them because they are not required to perform academically. Also, life skills so they can live independently, help themselves for their basic needs, able to interact with people around it well and have akhlaq as their provision to navigate their lives.

Character education and morals are essential for children with special needs because some children with special needs are not required to excel academically. They are more in lack of life skills to be able to live independently, be able to help themselves for their basic needs. They also should be able to interact with the people around them well and have the akhlaqul karimah as their provision to navigate their lives.

Several studies have shown that children with special needs need to develop character and character education, such as the results of

\footnotetext{
${ }^{6}$ Act of the Republic of Indonesia Number 20, Year 2003 On National Education System.

7 Bayu Pamungkas, "Urgensi Pendidikan Karakter Untuk Mengoptimalkan Layanan Pendidikan Bagi Siswa Berkebutuhan Khusus Di Sekolah Inklusif” (2016).
} 
research by Nurwahyuni et al. Published that children with special needs in children Attention Deficit Disorder (ADD) show the development of critical social skills. Based on the findings of the field for aspects of cooperation, children with special needs have excellent cooperation skills. It showed from the results of interviews with several informants about social skills in the issue of collaboration. The seven indicators that asked turned out to meet five symbols for the aspects of cooperation, namely listening to other people talk, doing tasks on time, utilizing free time, and following directions and instructions. Whereas the two indicators that did not meet are using the right tone of voice and the ability to ignore interference. ${ }^{8}$

Research supported by the Paternite study cited by Atien Nurchamidah et al. that explained successful interventions could reduce the new cases incidence and reduce the mental health disorders prevalence in children with special needs. This study showed that school-based mental health programs could reduce the occurrence of social and economic problems. ${ }^{9}$

Al-Ghazali Inclusion Elementary School Jatinangor Sumedang, West Java as one of the Islamic educational institutions is one of the inclusive elementary schools that accept children with special needs. It did as a form of concern for education is no exception to learning for them. Al-Ghazali Jatinangor Inclusive Elementary School seeks to contribute to the community in terms of education and assist the government by organizing knowledge that does not discriminate against children of ethnicity, religion, race, class or physical condition.

There are many ways, approaches, programs and activities that have been designed and implemented by Al-Ghazali Jatinangor Elementary School to instil akhlaq education for their

\footnotetext{
${ }^{8}$ Nurwahyuni Idris, "Social Skill Analysis in Children with Special Needs," Jurnal Nalar Pendidikan, vol.6, no.2, (2018), p.148, file:///D:/Jurnal Bahan/Anak ABK.pdf, accessed May 26, 2020,

9 Atien Nur Chamidah, "Pengembangan Panduan Layanan Kesehatan Mental Berbasis Sekolah Bagi Anak Berkebutuhan Khusus, Jurnal Penelitian IImu Pendidikan," Jurnal Penelitian Ilmu Pendidikan, vol.8, no. 2(2015),p.11, https://journal.uny.ac.id/index.php/jpip/article/ view/8267/6903, accessed May 28, 2020.
}

students, both regular children, and children with special needs. The learning activities program is designing so the program can implement to needs of each individual and under the stages of child development. So that both typical children and children with special needs can be well served and woke up at every stage of its growth also built good character and akhlaq.

\section{Method}

This research uses a descriptive method with a phenomenological qualitative approach. It aimed to understand, uncover and explain various visible phenomena. Thus, the purpose of the study is to discover facts, circumstances, events, variables, and conditions that occur during the research by displaying the effects as they are. ${ }^{10}$

The first stage of data collection in this study is observation. It made on the Al-Ghazali Inclusion Elementary School as research objects. Second, interviews, that were conducted with teachers, principals, and some parents of students to get information that was less than triangulation for data accuracy. Third, documentation, by making in the form of images, or files relating to the educational process at the school. Fourth, Focus Group Discussion or FGD, FGD is conducted with several people who are assumed to understand the research problem. Then, the data is analyzed, which used uses interactive model analysis, namely data collection activities, data reduction, data presentation, and concluding/verification.

Stages of analysis conducted after data collected are: First, data reduction and it is displayed summarized, classified, focused on the main things that are important for finding main ideas and patterns. Second, data display, then the reduced data presented in an organized description supported by diagrams, figures or graphs. Third, drawing conclusions and verification. This activity is the result that answers the focus of research based on data analysis. Findings presented in the form of descriptive objects based on the studies."

10 Sugiyono, Metode Penelitian Kuantitatif, Kualitatif, ((Bandung: CV Alfabeta, 2016), p.56.

${ }^{11}$ Matthew B Miles and Michael A. Huberman, Analisis Data Kualitatif: Buku Sumber Tentang Metode-Metode Baru, (Jakarta: Universitas Indonesia_UI Press, 2012) 


\section{Result and Discussion The child with special needed}

If you find the term child with special needs, this expressly aimed at children who have abnormalities/deviations from the average children's condition in general, both in terms of physical, mental, and social behaviour characteristics. ${ }^{12}$ This term used more wisely to refer to special children because they are generally not different from the others, only in certain aspects they need more attention.

Children with special needs are those who need special handling because of developmental disorders and abnormalities experienced. ${ }^{13}$ Meanwhile, the Ministry of Women's Empowerment and Child Protection of the Republic of Indonesia 2013; explained that children with special needs are who experience limitations or are physically, mentally-intellectually, socially, and emotionally which significantly influence their growth or development process compared to other same-age children. ${ }^{14}$

Children with special needs have several terms as variations of special needs, such as disability, impairment dan handicap..$^{15}$ According to the World Health Organization (WHO), each term has the following meaning; (1) Disability means someone who has limitations or deficiencies in the ability to display activities that are following the rules or are still within normal limits, usually used at the individual level. (2) Impairment; someone who has deficiencies or abnormalities in psychological development or anatomical structure and function. Traditionally used at the organ level. (3) Particular disadvantage resulting from impairment or disability that limits or

${ }^{12}$ Nandiyah Abdullah, "Mengenal Anak Berkebutuhan Khusus," Magistra , vol.86, Desember (2013), pp. 1-6.

${ }^{13}$ Dinie Ratri Desiningrum, Psikologi Anak Berkebutuhan Khusus, (Yogyakarta: psikosain 2016).

${ }^{14}$ It was written by Dinie Ratri Desiningrum, "Analisis Kebutuhan Pada Keluarga Yang Memiliki Anak Berkebutuhan Khusus" (2018), p. 106.

${ }^{15}$ Pastiria Sembiring Rafael Lisinus, "Pembinaan Anak Berkebutuhan Khusus (Sebuah Perspektif Bimbingan Dan Konseling)" Google Buku, https://books.google.co.id/book s?id=5GLLDwAAQBAJ\&pg=PA92\&dq=pendidikan+karakter +anak+berkebutuhan+khusus\&hl=id\&sa=X\&ved=oahUKEw jU79TL5vfnAhXUSHoKHZOKDx8Q6AEIODAC\#v=onepage\&q=pendidikan karakter anak berkebutuhan khusus\&f=false. accessed March 1, 2020, inhibits the fulfilment of a reasonable role for the individual. ${ }^{16}$

According to the IDEA or Individuals with Disabilities Education Act Amendments created in 1997 and reviewed in 2004: in general, the classification of children with special needs is ${ }^{17}$ :

\section{Children with Physical Disorders:}

a. Blind, that is, children whose sense of sight does not function (blind/low vision) as a channel for receiving information in daily activities such as alert people.

b. Deaf, a child who loses all or part of the hearing power so that they less able to communicate verbally.

c. Physically handicapped, a child who has defected permanently in the locomotor part (bones, joints, and muscles).

\section{Children with Emotional and Behavior} Disorders:

a. Children with Emotional Disorder, namely children who have difficulty adjusting and behaving are not under applicable norms.

b. Children with communication disorders can be called speech-impaired, i.e. children who experience voice abnormalities, articulation (pronunciation), or fluency of speech, which results in deviations in the form of language, the contents of communication, or language functions.

c. Hyperactivity, an abnormal behaviour disorder caused by neurological dysfunction. With the main symptoms. They are unable to control movement and focus attention.

\footnotetext{
16 Fikri Aulia, "VIEW of KONSEP KONSEP PENGEMBANGAN LAYANAN BAGI ANAK BERKEBUTUHAN KHUSUS PADA KURIKULUM 2013," JCOSE Jurnal Bimbingan Dan Konseling, vol.1, no.2 (2019), http://jkp.upstegal.ac.id/ index.php/jkpancaksakti/article/view/27/17, accessed March 1, 2020. See. also, Fitra Elnurianda, Umar Fauzan, and Syeh Hawib Hamzah. "The Implementation of Islamic Education Teaching at Inclusive Schools in Samarinda, East Kalimantan." MADANIA: JURNAL KAJIAN KEISLAMAN, vol. 22, vol. 2 (2018): pp. 173-184.

17 Dinie Ratri Desiningrum, "Psiokologi Anak Berkebutuhan Khusus," Psikosain , vol.15, no.1, (2016), pp.42-54.
} 


\section{Children with Intellectual Disorders:}

a. Mental retardation, which is a child who is experiencing obstacles and underdevelopment of intellectual, spiritual development is far below average so that he has difficulty in academic, communication and social tasks.

b. Slow learners have an intellectual potential below average but not mental retardation (usually has an IQ around 70-90).

c. Children with unique learning difficulties, in particular academic tasks, especially in terms of reading, writing, and arithmetic or math skills.

d. Gifted children are children who have exceptional talent or ability and intelligence, namely children who have the potential information (knowledge), creativity, and responsibility for tasks above their age (regular children). To realize their potential to become real achievements, require special education services.

e. Autism is a developmental disorder of a child caused by a disruption in the central nervous system that results in a disturbance in social interactions, communication, and behaviour.

f. Indigo is a human who from birth has particular advantages that are not owned by humans in general.

\section{Inclusive Education for Children with Special Needs}

One of the things that encourage inclusive education for children with special needs is the convention on the right of persons with disabilities and optional protocols, which ratified in March 2007. In article 24 of this conference, it explained that each country is required to implement an inclusive education system in every level of education. ${ }^{18}$

This convention intended as an instrument of human rights with an explicit dimension of

18 N. Praptiningrum, "Fenomena Penyelenggaraan Pendidikan Inklusif Bagi Anak Berkebutuhan Khusus “ JPK (Jurnal Pendidikan Khusus), vol.7, no. 2 (2010), pp. 32-39, DOI: https://doi.org/10.21831/jpk.v7i2.774 accessed March 5, 2020. social development that reaffirms that all people with all types of disabilities must enjoy all human rights and fundamental freedoms. The convention clarifies requirements apply to persons with disabilities and identifies areas where adaptation must be made for persons with disabilities to effectively use their rights and spaces in which their rights violated, and where the protection of rights must strengthen. ${ }^{19}$

One important thing that often overlooks for children with this limitation is the problem of education. So, the state should be present. The state can also move the community so that the rights of education for children with this limitation can obtain with good access and processes.

At least the educational goals of children with special needs, according to FAPE, are as follows:

1. Ensure that all children with identified disabilities receive special education and related services to meet their individual needs.

2. Ensure that children with disabilities prepared for work and independent living.

3. Ensure that the rights of children with disabilities and their families protected by law.

4. Assess and ensure the efforts of institutions that provide services for people with disabilities.

5. Assist states, localities, federal agencies, and educational service agents in providing education for children with disabilities. ${ }^{20}$

An inclusive school is a school that organizes an education delivery system that provides opportunities for all students who have disabilities and have the potential intelligence and/or unique talents to attend education or learning in the educational environment together with students in general. ${ }^{21}$

19 "Convention on the Rights of Persons with Disabilities (CRPD) | United Nations Enable," https://www.un.org/ development/desa/disabilities/convention-on-the-rights-ofpersons-with-disabilities.html. accessed March 5, 2020.

20 "What Is the Individuals with Disabilities Education Act? | DO-IT," https://www.washington.edu/doit/what-individualsdisabilities-education-act, accessed March 5, 2020.

21 "Kemendikbud Ajak Daerah Tingkatkan Pendidikan Inklusif" https://www.kemdikbud.go.id/main/blog/2019/07/ kemendikbud-ajak-daerah-tingkatkan-pendidikan-inklusif, accessed March 12, 2020. 
While individual schools or Sekolah Luar Biasa (SLB) are educational institutions that are prepared to handle and provide educational services, specifically for people with certain types of disorders ${ }^{22}$.

However, inclusive schools are indeed more typical children compared to children with special needs while particular schools provided for schools of children with special needs.

Inclusive education is a form of education that unites children with special needs with regular children in general to learn. According to Hildegun Olsen cited Tarmansyah, ${ }^{23}$ inclusive education is that schools must accommodate all children regardless of physical, intellectual, social-emotional, linguistic or other conditions. ${ }^{24}$ Must include children with disabilities, gifted. Street children and child workers come from populations isolated or nomadic. Children from ethnic minority, linguistic, or cultural populations and children from disadvantaged or marginalized areas or groups..$^{25}$ From some opinions, it can conclude that inclusive education is an educational service for students with special needs regardless of physical, intellectual, social-emotional, linguistic conditions or other conditions to get joint education services in regular schools.

Meanwhile, the models of inclusive schools conducted in Indonesia, according to Ashman, cited Emawati ${ }^{26}$ are as follows:

1. Regular Class (Full Inclusion)

Children with special needs learn with children throughout the day in regular classes using the same curriculum.

${ }^{22}$ Mimin Casmini, “Konsep Dasar Pendidikan Segregasi”, Pendidikan Segregasi, (2020).

${ }^{23}$ Tarmansyah, Inklusi Pendidikan Untuk Semua. (Jakarta: Depdiknas, 2007), p.82

24 Suharni, "Pemahaman Guru Dalam Layanan Bimbingan Pada Sekolah Penyelenggara Pendidikan Inklusi (Studi Lapangan Pada Sekolah Penyelenggara Inklusi), Jurnal CARE Edisi Khusus Temu Ilmiah, vol.3, no.3, (2016), p.5 " http://e-journal.unipma.ac.id, ccessed March 12, 2020.

${ }^{25}$ Eka Sari Setianingsih, "Penerimaan Dan Sikap Guru Terhadap Keberadaan ABK Di Sekolah," Empati (Jurnal Bimbingan dan Konseling), vol. 5, no.1 (April 2018), p. 38 http://journal.upgris.ac.id/index.php/EMPATI/article/ view/2929/2106, accessed March 9, 2020.

${ }^{26}$ Emawati, "Mengenal Lebih Jauh Sekolah

Inklusi" Pedagogik Jurnal Pendidikan, vol. 5, no.1 (2008). pp.25-35.
2. Regular class with Clusters

Children with special needs learn with regular children in regular classes in select groups.

3. Regular Classes with Pull Out

Children with special needs learn with other children in regular classes but at certain times are drawn from regular classes to separate rooms to study with individual tutors.

4. Regular Classes with Clusters and Pull Outs Children with special needs learn with norm children in regular classes in particular groups, and at certain times are drawn from regular classes to other types to study with individual supervisors.

5. Unique Classes with Various Integration Children with special needs learn in select classes in regular schools, but in specific fields can study with other children in daily grades.

6. Full Special Classes

Children with special needs learn in special classes at regular schools. ${ }^{27}$

\section{Character and Akhlaq Concepts}

In a large Indonesian dictionary, characters are; mental, moral or akhlaq characteristics that distinguish one person from another; nature; character. ${ }^{28}$ Meanwhile, akhlaq comes from Arabic jama "from the form of mufradat "khuluqun" which means: character, temperament, behaviour, and nature. ${ }^{29}$

When viewed from a linguistic understanding, the meaning of the word 'character' with 'akhlaq' seems to have almost the same purpose. However, if you see the knowledge in more depth, you will see the difference.

According to W. B. Saunders, the character is the real and different nature exhibited by

${ }^{27}$ Indah Permata Darma \& Binahayati Rusyidi, Pelaksanaan Sekola Inklusi Di Indonesia, vol. 2 no. 2 (2015), p.22, http://journal.unpad.ac.id/prosiding/article/ view/13530/6317, accessed March 12, 2020.

${ }_{28}$ Pusat Bahasa Kemdikbud, "Kamus Besar Bahasa Indonesia ( KBBI )," Kementerian Pendidikan dan Budaya (2016).

${ }^{29}$ Syarifah Habibah, "Akhlak Dan Etika Dalam Islam," Jurnal Pesona Dasar, vol. 1, no. 4, (October 5, 2015), p.73. 
individuals. The style can see from various attributes that exist in individual behaviour pattern ${ }^{30}$

Character education comes from many things; based on religion ${ }^{31}$ (all religious teachings), cultural values ${ }^{32}$, and human reason ${ }^{33}$.

Meanwhile, in the Islamic concept, akhlaq have an essential, tremendous and sacred meaning. According to Muslim Nurdin, akhlaq is a value system that regulates patterns of human attitudes and actions on the face of the earth. The value system in question is the teachings of Islam which are guided by the Quran and Sunnah of the Prophet Muhammad. ${ }^{34}$

The word akhlaq itself is listed in the Quran and also in Hadith:

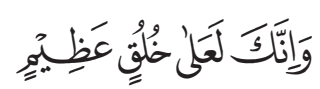

"Truly You (Muhammad) have a great (khuluq)." (Surah Al-Qalam [68]: 4)

In a hadith the Prophet Muhammad said:

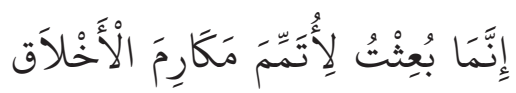

"I was sent only to perfect good akhlaq" (Narrated by Bukhari, Muslim, and Al-Hakim).

In another hadith narrated by Imam Muslim, it is explained that: 'Aisyah radhiyallahu anha was once asked about the akhlaq of the Prophet sallallaahu "Alayhi wasallam, then the mother "Aisyah r.a. answer: "Kâna Khulukuhul Qur'ân" means: "His akhlaq is the Quran." 35

30 Sigit Riyadi, "Sistem Informasi Berbasis SMS Gateway Pemantau Perkembangan Karakter Siswa Menggunakan Skala Likert, " Jurnal Spirit, vol. 8, no. 1, (2016), p. 18, http://jurnal.stmik-yadika.ac.id/index.php/ spirit/article/view/48/28accessed March 12, 2020,.

${ }^{31}$ I Ketut Sudarsana Kadek Dedy Herawan, "Relevansi Nilai Pendidikan Karakter Dalam Gegurita Suddhamala Untuk Meningkatkan Mutu Pendidika Di Indonesia," Jurnal Penjamin Mutu, vol. 3, no, 2 (2017), p. 227, http://www. ejournal.ihdn.ac.id/index.php/JPM/article/view/203/170. accessed March 15, 2020.

32 Emi Ramdani, “Model Pembelajaran Kontekstual Berbasis Kearifan Lokal Sebagai Penguatan Pendidikan Karakter," JUPIIS: JURNAL PENDIDIKAN ILMU-ILMU SOSIAL vol. 10, no. 1, (June 29, 2018), pp. 1-10.

33 Kamaruddin bin Wan Ali, "Kontribusi Salman AlFarisi Dan Kebudyaan Persia Dalam Pemikiran Islam," TOLERANSI: Media Ilmiah Komunikasi Umat Beragama, vol. 1, no. 1, (January 9, 2009), pp. 1-16.

34 Manpan Drajat and Ridwan Effendi, "Etika Profesi Guru,"( Bandung: Alfabeta, 2014), p. 19.

${ }_{35}$ Mildayanti, "Pengembangan Game Edukasi 'Tajwid Al-Quran’ Berbasis Android,” Karmapati, vol. 5, no. 2 (2016)
Thus, the akhlaq in Islamic teachings are sacred and have a profound meaning. It is the task of Muhammad's prophetic treatise. And also, it is the value of human virtue which based on the benefits of revelation.

In this case, the common thread can draw that character education, and akhlaq education in some aspects are similar, but in many cases, there are many differences. More important than that, the most fundamental difference is a different source of value.

Character education in Islamic education is something important to do. Still, all remains returned to the values rooted in the Quran and Sunnah as a standard assessment to determine whether a character which meant that acceptance or rejection.

While akhlaq education is a necessity that must give in the process of learning for Muslims, because of akhlaq education is part of the foundation of religion, and all the values taught in akhlaq_education rooted in the Quran and Sunnah.

\section{Character Education and Akhlaq of Children with Special Needs}

Character education has become a trend and is a concern of the community and educational institutions. At the same time, the community and the management of educational institutions realize that character education is essential to convey even as early as possible so that one day they become a generation of not only intelligent but have good character.

The Indonesian government currently has given full attention to character education. One of the efforts undertaken by the government is to issue policies that support this character education. Including the birth of the Republic of Indonesia's Presidential Regulation No 87 of 2017 concerning Strengthening Character Education or PPK. ${ }^{36}$ In this regulation, it stated that the Strengthening of Character Education. in the

\footnotetext{
, p. 15, DOI: http://dx.doi.org/10.23887/karmapati.v5i2.8302, accessed March 14, 2020.

${ }^{36}$ Presidential Regulation (Perpres) Number: 87 of 2017 concerning Strengthening Character Education.
} 
future referred to as PPK, is an educational movement under the responsibility of the education unit to strengthen the character of students. Through the harmony of hearts, tastes thought processes and sports with the involvement and cooperation between education units, families and the community as part of the National Mental Revolution Movement (GNRM).

Likewise, as a Muslim, akhlaq education is critical given to children as early as possible. Because in Islamic teachings, good akhlaq is the key so that humans can survive in the world and the hereafter. In a hadith, Prophet Muhammad,PBUH, said:

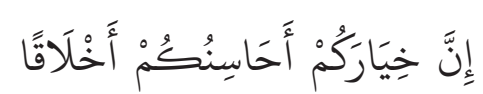
Surely the best among you is the best of akhlaq." (HR. Ahmad)

In another hadith Prophet Muhammad, PBUH said:

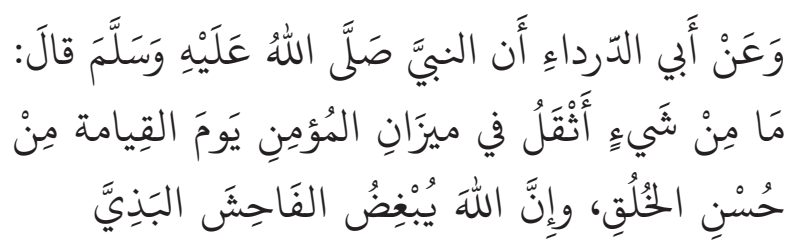
"From Abu Darda 'radhiallahu anhu that the Prophet sallallaahu alayhi was sallam said," There is nothing more massive in the scales of a believer someday there is a doomsday than akhlaqul karîmah. Surely Allah is very angry with someone wicked and evil." (HR. Tirmidhi)

The study of various researches, as well as expert opinion, states that education is crucial to value given to children and will better give from the age they are still young. ${ }^{37}$

Marzano and Bruner explained that the lower the level of education, the higher the portion for attitude education (in the opinion of the writer including character education and akhlaq) and the smaller the portion for knowledge and skills. Meanwhile, the higher the level of education, the lower the part for attitude education and the higher the building knowledge and skills..$^{38}$ The

${ }^{37}$ Sari, "Dongeng Sebagai Media Penanaman Karakter Pada Anak Usia Dini," Jurnal Pendidikan dan Pembelajaran Anak Usia DIni, vol.2, no.2 (2015), p 96, https://journal. trunojoyo.ac.id/pgpaudtrunojoyo/article/view/2606/2119. 2020, accessed March, 9.

38 Apiek Gandamana, “Integrasi Pendidikan Anti balance of educational content from elementary school to college-age illustrated in the chart below:

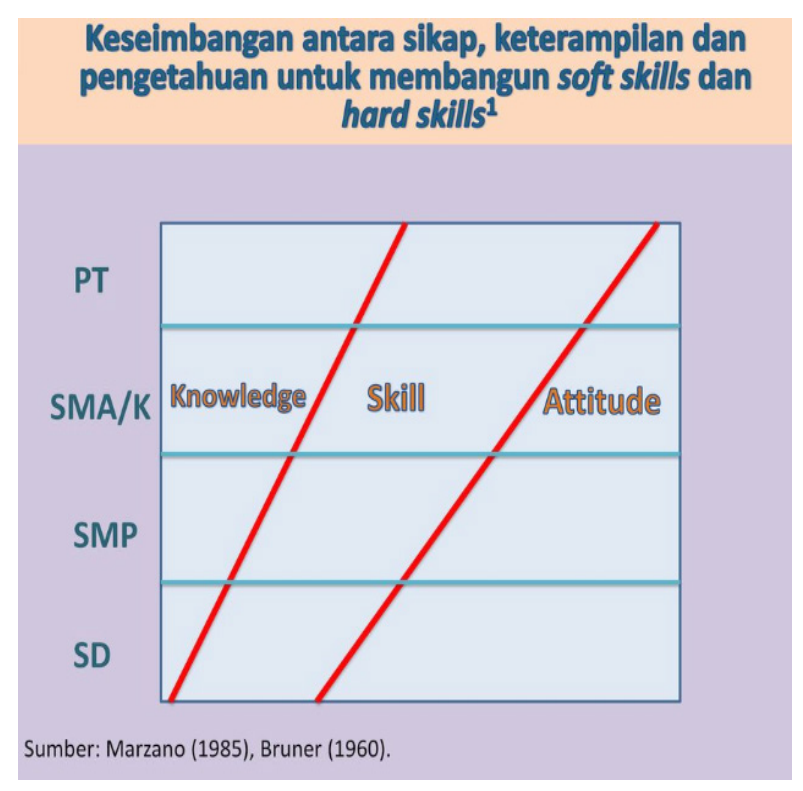

Character education and akhlaq at this age are critical because this golden period will determine the growth and development of children when they grow up. Character education and akhlaq are important given to children so that one day they grow up to become a civilized society. Because of attitude, culture in society will shape the character of a nation. Lickona in his book entitled "Education for Character: How Our Schools Can Teach Respect and Responsibility" states that one of the reasons why attitude education needed for a nation is the fact that the most striking deficiencies in children are in terms of values moral values. 39

Likewise, for children with special needs, they also need character education and akhlaq, because children with special needs also have good and bad behaviour. The behaviour varies greatly depending on the situation and conditions and how parents, teachers and the environment educate them.

Narkoba Dalam Pembelajaran Tematik Kurikulum 2013 Di Sekolah Dasar," Jurnal Keluarga Sehat Sejahtera vol. 14, Desember 2016, p. 40, file:///E:/Jurnal Bahan/Jurnal Marzano.pdf.

39 Thomas Lickona, Mendidik Untuk Membentuk Karakter: BagaimanaSekolah Dapat Memberikan Pendidikan Sikap Hormat Dan Bertanggung Jawab. (Penerjemah: Juma Abdu Wamaungo) (Jakarta: Bumi Aksara, 2012). 
In children with special needs, there is usually a gap between chronological age (birth age) and biological age (developmental age). It is evident in the display of their behaviour. In children with Down Syndrome (DS), for example, it is often considered "stubborn", which is the term used to describe rejection or silence is not obedient to instructions. They often tantrum or rage if the request disobeyed.

Also, in the case of cognitive development, some researchers say that exercise can optimize the Intelligence Quotient (IQ) of people with Down syndrome. From several studies, it knows that children with DS who given early training will increase their intelligence $20 \%$ higher than when they started attending formal school..$^{40}$

The earlier they receive stimulation, it will have implications for changes in the stages of the development of their attitudes, according to the research, the increase is significant. To provide direction or objectives to be achieved in carrying out a personal development program, the teacher must determine the abilities and indicators that can be used as a reference in planning, implementing, and assessing self-development activities for students. Examples of independent character competencies of children with special needs with indicators of being able to eat and drink with the right way and under the rules of eating in the teachings of Islam or Islamic akhlaq, ready to clean and maintain physical health in the right direction, able to take off and wear clothes properly.

\section{Model of Character Education and Akhlaq of Children with Special Needs in Al-Ghazali Jatinangor Inclusion Elementary School}

If you look at the concept of inclusive schools, according to Ashman (1994) as discussed above, then the Al-Ghazali Jatinganor Inclusion Elementary School is included in category number four. Namely, special-born children learning together with other children, at individual children with special needs are drawn from regular groups to get different programs from specialized teachers.

40 POTADS, Trisomy-21, Down Syindrome, (Jakarta: Gramedia, 2014).
According to the observations, there are at least three ways in the Al-Ghazali Jatinangor Inclusion Elementary School in building children's character and character, this method applies not only to children but also applies to children with special needs. The first is modelling. The model is an excellent example for children in building akhlaq as well as building other aspects. The teacher becomes a model for students. In addition to the teacher, average students will also be a model for other children with special needs.

Modelling has a powerful impact on building the character and akhlaq of children because one of the characteristics of early childhood is a master copycat. He will do what he sees; if what he sees then is done repeatedly, then this will form good habits. Similarly, children with special needs, they will do the same thing from what they see. In some cases, in the field. Even they are more consistent in applying good behaviour because they tend to follow the original pattern they receive from the modelling and habituation used by the teacher.

Examples of teacher modelling conducted include; the teacher always speaks softly using stomach sounds, speaking builds an attitude of respect. The teacher models an approach of respect to children with special needs by speaking softly, not shouting when teaching and learning activities take place. This slow talk makes the classroom atmosphere conducive and makes it easy for children to regulate themselves when there are things that cause them discomfort.

Another example of modelling done by teachers at Al-Ghazali Jatinangor Inclusion Elementary School is a model teacher who always says permission when leaving a group to do something that has a clear purpose. Like when you want to move to the toilet, proceed to take learning media. In addition to permission to leave the group, the teacher also models to say agreement when borrowing objects belonging to children or school property. Saying this permission instils honesty, equivalent word, and deed.

There is still a lot of modelling that must be carried out by the teacher consistently and becomes a Standard Operating Procedure (SOP) in every activity or program carried out by the 
teacher to build character and character for children, both regular children and children with special needs. If teachers found to have violated SOPs in this modelling, some sanctions will receive by the teacher. It did maintain a constant rhythm in character education and akhlaq with this modelling approach.

The second is a habit. Schools make habituation programs in the form of daily routines or one-day activities at school, all of these activities aim in addition to meeting the development of children's educational needs in general, also to build character and akhlaq in children. The routine event starts from the arrival of children at school until their return.

In every routine activity that has designed, there are work procedures or SOPs that must follow, both the teacher and the child must do it consistently, for example when the gth activity is lunch and brush your teeth.

When eating activities, children are accustomed to being patient waiting their turn, eating utensils rotated around all friends until they are all divided. Rice and side dishes also switched, each child will take enough food, they must be responsible for spending food that has made, no food may the remaining. After all, get their respective parts, then the new eating activities can begin after starting with a prayer before eating, after eating events finished, the child waits for his friends to finish eating all then closed with prayer after eating. After finishing eating, children do the cleaning up themselves, storing dirty utensils into a box and then returned to the kitchen. All are classified according to their groups between spoon with a spoon, fork with a fork, plate by plate.

Then in the activities of brushing teeth children must be queued, the child must bring their cup to rinse the mouth, after finishing brushing their teeth all children keep their toothbrushes and toothpaste back to the place.

The daily routine that has designed is not done in a hurry as long as all activities are fulfilled, but done carefully and accurately so that children can predict $t$, this builds patterns in children's minds so that they feel comfortable when doing each activity. From one event to another, there is something called transition. This transition time makes the classroom environment conducive, and children are much calmer, orderly and follow the rules.

For example, when the morning journal and free playtime will end soon, then 5 minutes before time runs out, the teacher will say, "The morning journal and free playtime is 5 minutes later". It allows children to prepare themselves to immediately complete activities then tidy up and make to enter the next action. Through this transition, the morals of discipline, responsibility, solemnity, are entirely built by the teacher.

This routine activity is designed not only for other children but also applies to children with special needs. This habit of morality is essential to be built on children from an early age so that it becomes a habit and eventually becomes the character and akhlaqul karimah.

The third is to use the Teacher Behavior Continuum method, a Non-Direct Teachinglearning approach consisting of five continuums conducted by teachers for students who have difficulty and need help or individual attention, the five continua are:

1. Visually looking on (observation)

2. Non-Directive statement (indirect statement)

3. Question

4. Directive Statement

5. Physical Intervention

Examples of implementation, when children are breaking the rules, leaving the group without permission, for example, the teacher will use a continuum of one (visually looking on), namely by observing what the child will do. If not finished with continuum one, then the teacher will do continuum two (Non-Directive Statement) by giving an indirect statement, for example, the report "Thank God, friends remain in the group with the teacher". If the child still does not understand the indirect statement, then the teacher will do a third continuum, which is to give a continuum three (Question), an example sentence sentence "What is the purpose of Hasbi moving out of the group? Need something?". If the child is still outside the group, then the teacher will use the fourth continuum, which 
is (Direct Statement), for example, a direct statement sentence such as "Hasbi group here, Together with Widya's mother, please re-join". If the child is still not back, the last step is the teacher will use the fifth continuum (Physical Intervention), that is with physical intervention, the teacher will move toward the child, then invite the child back into the group.

The program to strengthen character education and akhlaq for children with special needs was built at the Al-Ghazali Jatinangor Inclusion Elementary School from arrival to return. We call this the Daily Routine, we make character education and akhlaq through modelling and habituation or habit as well as the five accompanying continua with the term "return". Teacher Behavior Continuum or abbreviated as TB. This learning approach is Non-Direct Teachinglearning. The stages are as follows:

1. Visually looking on

2. Non-directive statement

3. Question

4. Directive statement

5. Physical intervention

This approach is carried out by the teacher for students who experience difficulties and need help or individual attention. Children with special needs tend to need help and personalized care. Therefore, this approach is critical and effective in educating them.

Several activities have been designed systematically and structured by teachers to build the character and character of regular children and children with special needs, including:

\section{Welcome School}

Teachers from 06:05 a.m conduct this Welcome School until 07.00 a.m. Every day the teachers at Al-Ghazali Jatinangor Inclusive Elementary School come to school at 06.00 a.m. Teachers arrive earlier than students; this is the teacher's transition time to prepare to welcome the arrival of all students. In this case, the teacher models the discipline, friendliness, affection, respect, and responsibility. Every day by greeting and smiling the teacher welcomes and greets the arrival of all students. When teachers greet and greet with greetings and smiles, all students will feel comfortable.

The cheerful for the teacher welcoming, students feel that a school is a safe place for them to learn and work.

In addition to welcoming students, another activity undertaken in this session is the setting of the primary environment. Because children will awaken to akhlaqul karimah if the teacher has prepared the environment setting, no programs are made impromptu and not planned. The modelling and habituation that the teacher prepares to build good character and character in children with special needs.

In contrast to healthy children, children with special needs need a longer transition time compared to healthy children. Therefore with sufficient welcome school activities, teachers are ready to greet them with greetings and greetings and environmental settings, making them more prepared to learn throughout the day at school.

\section{Morning Journal}

Morning journal activities carried out since the children arrive until 07.15 a.m. Every morning, the teacher has prepared an environmental setting for the morning journal activities in the room. The teacher makes plain HVS paper with coloured pencils, crayons, and markers. So, when the child comes and enters the classroom, each child sees the media the teacher has prepared, the child is ready to do the morning journal. Through this morning's journal activities, each child will develop an orderly, calm and disciplined attitude to the schedule the teacher planned.

This activity lasts for 15 minutes, and this activity is a time of transition for students. The transition from home to school, if children feel uncomfortable at home or during the trip, they can calm down first, take a deep breath, regulate themselves first with journal activities in the room. The child's brain needs preparation to be ready to learn. Similarly, children with special needs, they need time to transition.

Activities that children do when journaling is drawing freely for children who cannot write. But if children can write, they will write down 
what they do while at home from waking up to arriving at school.

Before the morning journal time is over, the teacher will convey the transition time, "Journal time is 5 minutes left", then when the time is really up the teacher will deliver the time out and count down. After the children finish the journal, they will report the pictures or writing they have made to the teacher. If time runs out, all the children and the teacher will tidy up the stationery and keep it in its original place. One of the benefits of the Morning Journal is to build trust in children with special needs. Because they did not force to do this activity, so they can do this critical activity with happy feelings, they can express their feelings by drawing in the morning journal.

\section{Pledges, Prayer, and Memorization of the Short Surah}

Pledges, prayers, and memorization of short Surah carried out from 07.15 a.m to 07.30 a.m.

After finishing the morning journal, the child will sit in a circle to make a pledge, pray before learning and memorizing short letters. This activity lasts for 15 minutes. Even children with special needs can memorize short letters and daily prayers without being forced to remember because they see and hear healthy children every day repeatedly.

\section{Dhuha Prayer and Outdoor Structured Activities}

The Dhuha prayer Activity and structured outdoor activities carried out from 07.30 a.m to $08.10 \mathrm{a} . \mathrm{m}$. Every day the teacher has made a set of environmental actions that build physical aspects of motoric. Here six basic movements are built. All children have the opportunity to do outdoor activities for 20 minutes. As usual, the prayer is complete, before leaving the room, all children must queue in line and pray out of the room first. After completing the activities, the children and the teacher will clean up the media used, then store the footwear on a shoe rack and then return to the room and read the prayers into the room. It builds good character and character such as discipline, patience, gratitude, sincerity, and also the responsibility.
Children with special needs can mimic prayer movements and prayer readings without having to be forced and in the drill learning prayer lessons because they see and hear the prayer activities of other regular friends. This activity can undoubtedly build their spiritual intelligence by their limits.

\section{Academic 1}

Academic activity 1 is a field of study activity. Educational activities are activities that span longer than all the activities carried out since the child arrives until returning home. Educational event 1 took place from 08.10 a.m until 09.45 a.m.

Here, children learn to explore by using all their abilities through various tools that support the development of knowledge in each field of study in their classrooms.

In this activity, children with special needs carry out independent activities with individual assistant teachers according to their developmental stages. Activities vary depending on the type of specificity.

\section{Morning Snacks}

At Al-Ghazali Jatinangor Inclusion Elementary School, morning snack activities included in the learning program. Eating in this morning snack is not just filling a hungry stomach. Nor is it a supplementary feeding activity because the morning snack/snack activities carried out every day.

This morning snack activity carried out from 09.30 a.m until 09.45 a.m. After completing structured activities outside, all students will wash their hands, preparing for the morning snack or morning snack.

All children queue up to the washing tub, read prayers into the bathroom. They wash their hands, use hand washing soap. When finished, all the children queued back and read the prayer out of the shower.

After that, all children will sit in their respective groups and prepare cutlery. Take one by one cutlery and pieces of fruit, be patient waiting for their turn after all ready. Then the child recites prayers before eating. After 
finishing eating snacks, all the children read the prayer and then store the cutlery according to its classification. Akhlaq that built is patience, gratitude, sincerity, affection, clean, honest and responsibility.

Children with special needs in this activity can do activities well. Also, with this activity, they can learn many things like other regular children. They can learn about patience, responsibility, empathy, and so on.

\section{Literacy}

This Literacy Activity is an activity during the first literacy, carried out from 09.45 a.m until 10:00 a.m. This activity is a transition activity from snacks to core activities. Here children can play traditionally, read books, read the Quran, sing also play guess words. Every day the events that children do vary depending on the theme and stages of development of each child. The akhlaq that built during this activity is an attitude of love, respect, patience, and honesty.

Children with special needs can join in these activities such as playing traditional listening to teachers reading books, singing and so on. It can help the development stage of children with special needs, especially social development.

\section{Academic 2}

Academic activities 2 are the same as academic activities 1 . For educational activities 2, it s conducted from 10:00 a.m until 11:30 a.m. Classes 1 and 2 every day, there are only two academic activities. Then for grades 3, 4, 5 and 6 , there are three educational activities.

the same explanation with academic activities 1, children with special needs do independent activities with individual assistant teachers according to the stage of development

\section{Second Literacy}

The other literacy activity carried out for 15 minutes as the first literacy. The time range is from 11:30 a.m. until 11:45 a.m.

This activity is a transition from academic activities to lunch activities. Here the children will write down the knowledge they get from educational activities 1 and 2 . The character that built during this activity is the character of love, respect, patience, and honesty.

\section{Ablution and Prayer Dzuhur}

Dzuhur prayer activities held at 12:30 p.m until 13:00 p.m. After doing toothbrush and ablution activities, the children together with the teacher will pray the midday prayer and then do the dzikir, read the prayer, Asmaul Husna and memorize short Surah. Build good characters such as khusyu, taqwa, istiqomah, qonaah, and discipline.

Children with special needs felt the same benefits as in the explanation of the Duha prayer activities

\section{Lunch and Tooth Brushing}

Lunchtime is from 11:45 a.m until 12:30 p.m. After finishing playing at the centre and circle time, all students will wash their hands, preparing for lunch. All children queue up to the sink then read prayers into the bathroom. They wash their hands according to WHO standards (six hand movements) and use hand washing soap. When finished, all the children queued back and read the prayer out of the bathroom.

Then all the children will sit in their respective groups and prepare cutlery. Take one by one cutlery and take rice, vegetables and side dishes, be patient waiting their turn. After all ready, they recite the prayer before eating. After finishing lunch, all the children read the prayer and then store the cutlery according to its classification. Then they will queue back to the bathroom to follow the activity of brushing their teeth. Akhlaq that built is patience, gratitude, sincerity, affection, clean, honest and responsibility.

Similar to regular children, children with special learning needs also do what has done with their regular friends in this lunch activity.

\section{Academic 3}

Academic activity 3 is the same as educational 1 and 2. It is an activity field of study or subjects. Scholarly event 3 held from 01.30 p.m until 03.00 p.m 


\section{Clean Up and Prayer Ashar}

After completing academic 3, every child will do the cleaning up according to the designated picket schedule. After completing the activities tidying up, all the children will prepare to do the prayer Ashar.

Children with special needs are also required to carry out the same activities as regular children by their limits so that they get the same benefits from this activity.

\section{Afternoon Journal, Recalling, and Return}

This activity is the last activity carried out by children, carried out from 03:45 p.m until 04:00 p.m. After completing the prayer, dhikr and pray all the children will retell the events of a day at school through pictures or writing, also through word of mouth which we call recalling. The attitude that built is humble, patient, thankful, sincere, disciplined and responsible.

Before going home, regular children and children with special needs to do the same closing activities, they must get a cooling down after doing all-day activities with teachers and friends at school.

\section{Conclusion}

The concept of akhlaq education for children with special needs in the Al-Ghazali Jatinangor Inclusion Elementary School built in three ways. They are namely modelling, habituation and Teacher Behavior Continuum or Non-Direct Teaching-learning approaches. It consisting of five continuums, namely: visually looking on, non-directive statements, questions, directive statement, physical intervention, conducted by the teacher for students who have difficulty and need help or individual attention. All three are carried out by the teacher since the child comes to go home through a daily routine that has been made systematic and structured.

Implementation of character education and akhlaq behaviour with Modeling, Habit and Teacher Behavior Continuum, as follows a). The teacher models the characters and akhlaq that they want to build on children with special needs. In addition to the teacher, children also become models for building good character and character. b). Habit formed through a daily routine that has been designed systematically and structured since the child arrives home. In every activity, all styles and good characters built. c). Teacher Behavior Continuum is the action taken by the teacher in stages from the first action to the fifth action. All that was done by the teacher during the process of the activity took place from arrival to return.

\section{References}

Abdullah, Nandiyah, "Mengenal Anak Berkebutuhan Khusus," Magistra, vol.86, Desember, 2013.

Ali, Kamaruddin bin Wan, "Kontribusi Salman AlFarisi Dan Kebudyaan Persia Dalam Pemikiran Islam," TOLERANSI: Media Ilmiah Komunikasi Umat Beragama, vol. 1, no. 1, January 9, 2009.

"Act of the Republic of Indonesia Number 20, Year 2003 On National Education System.

"Aulia, Fikri, "VIEW of KONSEP KONSEP PENGEMBANGAN LAYANAN BAGI ANAK BERKEBUTUHAN KHUSUS PADA KURIKULUM 2013," JCOSE Jurnal Bimbingan Dan Konseling, vol.1, no.2 2019, http://jkp.upstegal.ac.id/ index.php/jkpancaksakti/article/view/27/17, accessed March 1, 2020.

"70 Persen Anak Berkebutuhan Khusus Tak Dapat Pendidikan Layak", https://lifestyle. bisnis.com/read/20190326/236/904431/70persen-anak-berkebutuhan-khusus-tak-dapatpendidikan-layak, accessed March 2, 2020.

"Casmini, Mimin, Konsep Dasar Pendidikan Segregasi, Pendidikan Segregasi, 2020.

"Chamidah, Atien Nur, "Pengembangan Panduan Layanan Kesehatan Mental Berbasis Sekolah Bagi Anak Berkebutuhan Khusus, Jurnal Penelitian Ilmu Pendidikan," Jurnal Penelitian IImu Pendidikan, vol.8, no. 2, 2015, https:// journal.uny.ac.id/index.php/jpip/article/ view/8267/6903, accessed May 28, 2020.

"Convention on the Rights of Persons with Disabilities (CRPD) | United Nations Enable,"https://www.un.org/development/ desa/disabilities/convention-on-the-rightsof-persons-with-disabilities.html, accessed March 5, 2020. 
Darma, Indah Permata \& Binahayati Rusyidi, Pelaksanaan Sekola Inklusi Di Indonesia, vol. 2 no. 2, 2015, http://journal.unpad.ac.id/ prosiding/article/view/13530/6317, accessed March 12, 2020.

Desiningrum, Dinie Ratri, “Analisis Kebutuhan Pada Keluarga Yang Memiliki Anak Berkebutuhan Khusus" ,2018.

Desiningrum, Dinie Ratri, "Psiokologi Anak Berkebutuhan Khusus," Psikosain, vol.15, no.1, 2016.

, Psikologi Anak Berkebutuhan Khusus, Yogyakarta: psikosain 2016.

Drajat, Manpan and Ridwan Effendi, Etika Profesi Guru, Bandung: Alfabeta, 2014.

Elnurianda, Fitra, Umar Fauzan, and Syeh Hawib Hamzah. "The Implementation of Islamic Education Teaching at Inclusive Schools in Samarinda, East Kalimantan." MADANIA: JURNAL KAJIAN KEISLAMAN, vol. 22, vol. 2, 2018.

Emawati, "Mengenal Lebih Jauh Sekolah Inklusi” Pedagogik Jurnal Pendidikan, vol. 5, no.1, 2008.

Gandamana, Apiek, “Integrasi Pendidikan Anti Narkoba Dalam Pembelajaran Tematik Kurikulum 2013 Di Sekolah Dasar," Jurnal Keluarga Sehat Sejahtera, vol. 14, Desember 2016, file:///E:/Jurnal Bahan/Jurnal Marzano. pdf.

Herawan, Kadek Dedy, and I Ketut Sudarsana, “Relevansi Nilai Pendidikan Karakter Dalam Gegurita Suddhamala Untuk Meningkatkan Mutu Pendidika Di Indonesia," Jurnal Penjamin Mutu, vol. 3, no, 2, 2017, http://www.ejournal. ihdn.ac.id/index.php/JPM/article/view/203/170. accessed March 15, 2020.

Habibah, Syarifah, "Akhlak Dan Etika Dalam Islam," Jurnal Pesona Dasar, vol. 1, no. 4, October 5, 2015

Idris, Nurwahyuni, "Social Skill Analysis in Children with Special Needs," Jurnal Nalar Pendidikan, vol.6, no.2, 2018, file:///D:/Jurnal Bahan/Anak ABK.pdf, accessed May 26, 2020.

“Inclusive Education" |UNICEF,", https://www. unicef.org/education/inclusive-education, accessed March 2, 2020.

“Jumlah Data Masuk Siswa Disabilitas di Sekolah Inklusif Masih Sedikit", https://edukasi.kompas. com/read/2019/11/28/14021431/jumlah-data- masuk-siswa-disabilitas-di-sekolah-inklusif-masihsedikit?page=all, accessed March 9, 2020.

"Kemendikbud Ajak Daerah Tingkatkan Pendidikan Inklusif" https://www.kemdikbud.go.id/main/ blog/2019/07/kemendikbud-ajak-daerahtingkatkan-pendidikan-inklusif, accessed March 12, 2020.

Lickona, Thomas, Mendidik Untuk Membentuk Karakter: BagaimanaSekolah Dapat Memberikan Pendidikan Sikap Hormat Dan Bertanggung Jawab, trans, Juma Abdu Wamaungo, Jakarta: Bumi Aksara, 2012.

Mildayanti, "Pengembangan Game Edukasi 'Tajwid Al-Quran' Berbasis Android," Karmapati, vol. 5, no. 2, 2016., DOI: http://dx.doi.org/10.23887/ karmapati.v5i2.8302, accessed March 14, 2020.

Miles, Matthew B and Michael A. Huberman, Analisis Data Kualitatif: Buku Sumber Tentang Metode-Metode Baru, Jakarta: Universitas Indonesia_UI Press, 2012.

Pamungkas, Bayu, “Urgensi Pendidikan Karakter Untuk Mengoptimalkan Layanan Pendidikan Bagi Siswa Berkebutuhan Khusus Di Sekolah Inklusif" , 2016.

Rafael Lisinus, Pastiria Sembiring, "Pembinaan Anak Berkebutuhan Khusus (Sebuah Perspektif Bimbingan Dan Konseling)" Google Buku, https://books.google.co.id/books?id=5GLLDw AAQBAJ\&pg=PA92\&dq=pendidikan+karakter+ anak+berkebutuhan+khusus\&hl=id\&sa=X\&ved =oahUKEwjU79TL5vfnAhXUSHoKHZOKDx8Q6 AEIODAC\#v=onepage\&q=pendidikan karakter anak berkebutuhan khusus\&f=false.accessed March 1, 2020.

POTADS, Trisomy-21, Down Syindrome, Jakarta: Gramedia, 2014.

Potret Pendidikan Statistik Pendidikan Indonesia 2019", https://www.bps.go.id/publication/20 19/11/29/1deb588ef5fdbfba3343bb51/potretpendidikan-statistik-pendidikan-indonesia-2019. html, accessed February 29, 2020.

Pramudiana, Ika Devi,"Implementasi Kebijakan Pendidikan Inklusif Untuk Abk di Surabaya" Jurnal Dimensi Pendidikan dan Pembelajaran, vol.5, no.1, 2017, doi:http://dx.doi.org/10.24269/ dpp.v5i1.317, accessed March 9, 2020.

Praptiningrum, N., "Fenomena Penyelenggaraan Pendidikan Inklusif Bagi Anak Berkebutuhan 
Khusus “ JPK (Jurnal Pendidikan Khusus), vol.7, no. 2, 2010, DOI: https://doi.org/10.21831/jpk. v7i2.774, accessed March 5, 2020.

Pusat Bahasa Kemdikbud, "Kamus Besar Bahasa Indonesia (KBBI)," Kementerian Pendidikan dan Budaya, 2016.

Ramdani, Emi, “Model Pembelajaran Kontekstual Berbasis Kearifan Lokal Sebagai Penguatan Pendidikan Karakter," JUPIIS: JURNAL PENDIDIKAN ILMU-ILMU SOSIAL, vol. 10, no. 1, June 29, 2018.

Sari, "Dongeng Sebagai Media Penanaman Karakter Pada Anak Usia Dini," Jurnal Pendidikan dan Pembelajaran Anak Usia DIni, vol.2, no.2, 2015.

Setianingsih, Eka Sari, "Penerimaan Dan Sikap Guru Terhadap Keberadaan ABK Di Sekolah," Empati (Jurnal Bimbingan dan Konseling), vol. 5, no.1, April 2018, http://journal.upgris.ac.id/ index.php/EMPATI/article/view/2929/2106, accessed March 9, 2020.
Riyadi,Sigit, "Sistem Informasi Berbasis SMS Gateway Pemantau Perkembangan Karakter Siswa Menggunakan Skala Likert, " Jurnal Spirit, vol. 8, no. 1, 2016, 18, http://jurnal. stmik-yadika.ac.id/index.php/spirit/article/ view/48/28, accessed March 12, 2020.

Sugiyono, Metode Penelitian Kuantitatif, Kualitatif, Bandung: CV Alfabeta, 2016.

Suharni, "Pemahaman Guru Dalam Layanan Bimbingan Pada Sekolah Penyelenggara Pendidikan Inklusi (Studi Lapangan Pada Sekolah Penyelenggara Inklusi), Jurnal CARE Edisi Khusus Temu Ilmiah, vol.3, no.3, 2016," http://e-journal.unipma.ac.id, accessed March 12, 2020.

Tarmansyah, Inklusi Pendidikan Untuk Semua, Jakarta: Depdiknas, 2007.

What Is the Individuals with Disabilities Education Act? | DO-IT," https://www.washington.edu/ doit/what-individuals-disabilities-educationact, accessed March 5, 2020. 